https://doi.org/10.19195/0137-1150.173.15

Data przesłania artykułu: 5.09.2019

Data akceptacji artykułu: 13.02 .2020

\author{
IRENA BETKO
}

Uniwersytet Warmińsko-Mazurski w Olsztynie, Polska

\title{
Психобіографічне підгрунтя інтимної лірики Тараса Шевченка
}

Лиш нечисленні знають, що греки, творці різноманітних мистецтв, відкрили також і мистецтво пам'яті, яке разом з іншими було передано Риму й пізніше увійшло до європейської традиції. [...] За одним із грецьких міфів, Мнемозина є матір'ю муз; історія розвитку цієї найфундаментальнішої, а водночас незбагненної людської здібності змушує нас зануритися на значно більшу глибину ${ }^{1}$.

Зацитовані міркування, висловлені Френсіс Йейтс у вступі до книги Мистеитво пам'яті, у певному сенсі можуть бути відчитані як заохочення до рефлексії над глибиннопсихологічними первнями засигналізованої в титулі „незбагненної людської здібності”. Пам'ять-Мнемозина, породжуючи одну зі своїх дочок - музу історії Кліо, розкрила тим самим внутрішіній простір для історіософії як адекватної стратегії проникнення в глибинну істоту подій, пов'язаних з буттям держав і народів. Коли ж ідеться про історичну долю окремого індивіда, зафіксовану у меморіальних жанрах біографії чи автобіографії ${ }^{2}$, виникає настійна потреба осмислення іiі психобіографічного контексту, що враховує часом глибоко приховані символічні аспекти духовного розвитку особистості, висвітлюючи відповідним чином істинний сенс iї людського існування.

Оскільки сенс існування того чи іншого письменника безпосередньо пов' язується з його літературною спадщиною, остільки і психобіографія митця слова, як правило, розбудовується на подвійному матеріалі - власне біографічному та літературно-художньому. Одним із яскравих унаочнень цієї

${ }^{1}$ Ф. Йейтс, Искусство памяти, пер. Е. Малышкин, Санкт-Петербург 1996, с. 6 [Тут і далі переклад з російської мій. - І. Б.].

2 Див. M. Marszałek, Autobiografia; K. Kaźmierska, P. Czapliński, V. Julkowska, Biografia, [в:] Modi memorandi: Leksykon kultury pamięci, ред. M. Saryusz-Wolska, R. Tadla, співпр. J. Каlicka, Warszawa 2014, c. 53-58, 61-67. 
тези може служити феномен Тараса Шевченка, чиї твори у вельми небанальний спосіб перегукуються з відповідними сторінками книги його життя.

У Передньому слові до другого видання ліричної драми Зів'яле листя Іван Франко охарактеризув свої ліричні пісні як найсуб 'єктивніші „із усіх, які появилися у нас від часу автобіографічних поезій Шевченка"з. Нав'язуючи в окресленому контексті до традицій свого великого попередника, він фактично канонізує його як основоположника національної інтимно-любовної лірики, а також як автора поетичних текстів, позначених печаттю глибинної сугестії складного емоційного та психо-духовного досвіду видатної особистості.

Згадані Франком автобіографічні поезії Шевченка становлять осереддя його суб' єктивної лірики інтимно-любовної тематики. До їх числа сучасне шевченкознавство традиційно відносить твори, присвячені подрузі дитячих літ поета Оксані Коваленко ${ }^{4}$ (по чоловікові - Сорока, 1817-?), Ганні Закревській ${ }^{5}$ (дівоче прізвище - Заславська, 1822-1857) та служниці-кріпачці Ликері (Гликеріі) Полусмаківні ${ }^{6}$ (Полусмак, по чоловікові - Яковлєва, 1840-1917). На думку Юрія Барабаша, „«адресатні» любовні поезії Шевченка" повністю позбавлені

двозначного еротичного підтексту, [...] натяку на плотське бажання, жагу фізичного зближення, [...] просто вільного, «розкутого» слова на цю дражливу тему [...] Сама лишень світла печаль [...] сама туга за нездійсненим і нездійсненним щастям, сама трепетна ніжність. Шевченкова любов самовіддана, жертовна, він нічого не вимагає, не очікує від коханої жінки, лишень прагне віддати їй все, що може, що криється в його душі ${ }^{7}$.

Цими багато в чому справедливими міркуваннями вчений не обмежує тієї вічно актуальної наукової проблеми, яку становить настійна потреба щораз глибшого проникнення у святая святих Шевченкової душі, що на

3 І. Франко, Зів яле листя. Лірична драма, ідея та концепція видання, післямова М. Зубрицька, упоряд., підготовка текстів, наук. та літ. ред., пошук та фотокопіювання архівних джерел Б. Тихолоз, Львів 2006, с. VI.

4 Див. Оксані К…...ко. На пам'ять того, щзо давно минуло (ліричний вступ до незакінченої поеми Мар'яна-черниця, 1841). Згадки про Оксану Коваленко містяться також у поезіях Три літа (1845), Ми вкупочці колись росли... (1849), Не молилася за мене... (1850). Імовірно, що саме вона стала прототипом безіменної ліричної героїні вірша $N$. N. (Мені тринадиятий минало..., 1847). Тут і далі посилання на поезії Шевченка і цит. за: Т. Шевченко, Повне зібрання творів у шести томах, т. 1: Поезія 1837-1847, упоряд. та ком. І. Бажинов та ін., переднє слово I. Дзюба, М. Жулинський, ред. В. Бородін, Київ 2003; т. 2: Поезія 1847-1861, упоряд. та ком. В. Бородін et al., ред. В. Бородін, Київ 2003.

5 Див. Г. 3., Якби зострілися ми знову... (обидва твори 1848 р.). Не можна виключити, що саме до цієї жінки Шевченко звертається у вступній частині поеми Сліпий (1845). Також існує припущення, що ï ім'я може бути зашифроване в заголовку-присвяті вірша $N$. N. (Сонще заходить, гори чорніють..., 1847).

6 Див. Ликері, Л. (обидва твори 1860).

7 Ю. Барабаш, Любов (кохання, захоплення, пристрасть, уподобання, пасія), [в:] Теми i мотиви поезї̈ Тараса Шевченка, упоряд., наук. ред. Н. Чамата, Київ 2008, с. 189. 
радощі й терпіння буття рефлектувала невмирущими ліричними шедеврами. Назвавши основні праці в межах порушеного питання (у т. ч. авторства Степана Балея, Василя Пахаренка, Джорджа Грабовича та ін.), Барабаш слушно закидає сучасному шевченкознавству брак „виразно виявленої тенденції до [...] комплексного, контекстуального розгляду теми" любові у творчості пое$\mathrm{Ta}^{8}$. Якоюсь мірою виповнити цю прогалину дозволить спроба дослідження психобіографічного підгрунтя інтимної лірики Шевченка, що передбачає, серед інших методологічних пропозицій і підходів, застосування у даному випадку вельми перспективної стратегії архетипального / ритуально-міфологічного аналізу.

Серед адресаток любовних поезій Шевченка, яким на різних етапах життя і творчості поета судилося стати більш або менш вдячними об' єктами несвідомих глибиннопсихологічних проекиій 9 сокровенного жіночого образу душі митця, у т.ч. іiі яскравих архетипально-аніматичних мотивів ${ }^{10}$, справжньою fam fatal стала Ликера, що протягом 45 днів (від 27 липня до 10 вересня 1860 р.) була поетовою нареченою. На справедливу думку Павла Зайцева, переживання митця, викликані цим трагічним епізодом, „безперечно, вплинули на його передчасну смерть"11.

Цитуючи фрагмент листа Олександри Білозерської-Куліш (літературний псевдонім - Ганна Барвінок) до ніженського дідича, журналіста Миколи Макарова, Ликериного пана й опікуна, в якому йдеться про матримоніальні плани Шевченка („Як він засліплений! Поет і проза!”), Зайцев рефлектує: „Коли 6 хтось хотів описати докладно цей Шевченків трагічний роман, то, справді, не знайшов би кращого заголовку, як «Поет і проза»..."12. Саме в такій патетико-саркастичній тональності щодо прозаїчного предмету почуттєвого заангажування найбільшого поета України звучить лірична мініатюра Ліни Костенко, в якій афористично підсумовано тотальну дезапробацію Ликери зі сторони як близького оточення поета, так і наступних дослідників і шанувальників його творчості:

Той любить Фанні Брон, той любить Беатріче, / Лауру, Ганську або Наталі. / Коштовні імена на бархаті сторіччя! / Немеркнучі зірки на обріях землі! / О, скільки взято нот і списано паперу! / Шкода, як ореол не держиться чола. / Коли безсмертя впало на Ликеру, / вона якраз по бублики ішла ${ }^{13}$.

Тим часом фактографічно-документальний аспект розглядуваних подій Зайцев коментує мало не з позицій психо-екзистенційного агностицизму:

8 Ibidem, c. 187.

9 Див. D. Sharp, Leksykon pojęć i idei C. G. Junga, пер. J. Prokopiuk, Wrocław 1998, c. $132-135$.

10 Ibidem, c. 28-33.

11 Див. П. Зайцев, Життя Тараса Шевченка, Нью-Йорк-Париж-Мюнхен 1955, с. 349.

12 Ibidem, c. 355.

13 Цит. за: „Той любить Фанні Брон, той любить Беатріче...” Ліна Костенко, http:// osvita.ua/school/literature/k/70272/ [доступ: 05.02.2020]. 
Про історію цього останнього роману Шевченка оповідають нам численні документи: і листи самого поета, і листи Ликери, і тогочасне листування безпосередніх свідків та інших осіб, і широчезна мемуарна література. Ні про один з інших моментів Шевченкового життя не збереглося стільки матеріалів, скільки про цей трагічний епізод. А проте в усьому цьому багатющому «архівному фонді» стільки неясного, заплутаного, суперечливого та загадкового, що критично розібратися в ньому і вилущити всю правду до кінця не лише важко, а в деяких окремих моментах просто неможливо ${ }^{14}$.

Дослідник має рацію щодо проблематичності адекватного аналізу цієї архискомплікованої біографічної колізії, особливо якщо трактувати її самодостатньо, обмежуючись свідоцтвами суто зовнішнього, подієвого характеру. Адже як поет, так і його далека від досконалості обранка, - обоє, хоча й кожен на міру власних очікувань, були сповнені спочатку інфантильних фантазій щодо характеру їх майбутнього шлюбу, а потім, коли ілюзії швидко розвіялися, - взаємних претензій і деструктивних емоцій. Натомість опінії про цю справді проблематичну пару часом виголошували особи хоча й достойні, але психологічно вкрай невідповідні. Скажімо, на повірницю в справі сватання до Ликери Шевченко вибрав... давню приятельку пані Олександру, що на той момент була глибоко нещасна в особистому житті, тяжко переживаючи подружню зраду свого чоловіка Пантелеймона Куліша.

Можна все-таки спробувати пролити світло на даний епізод, поставивши його у цілісний контекст інтимної психобіографії Шевченка й розглядаючи як фінальний етап наскрізної внутрішньої психодрами поета, що іії рушійною силою стала динаміка переживання/перебігу материнського комплекcy (Sharp, c. 88-91), ніколи остаточно не компенсованого в межах свідомої особистості митця, хоча й великою мірою сублімованого у його геніальній творчості. Напрошується припущення, що саме цей глибиннопсихологічний конфлікт, не усвідомлений у повному обсязі й великою мірою витіснений (Sharp, c. 154-155), взагалі поносить відповідальність за глобальну трагедію поетової самотності, котру він украй тяжко переживав, а також за те, що його особисте життя так ніколи і не склалося. Має, отже, рацію наступне міркування Інни Кошової:

Жінки, яких обирав Шевченко для одруження, мали б створити родинний затишок, який поет утратив зі смертю матері. Але жодна з них так цього і не зробила. Йдучи за Фройдом, Шевченка можемо порівняти 3 «мрійником-серед-білого-дня», а поетові твори - 3 мріями, де яскраво фігурує мати («веселая присниться мати») $)^{15}$.

Приступаючи до безпосереднього розгляду того скомплікованого підгрунтя, на якому виростає інтимно-любовна лірика Шевченка, необхідно передусім усвідомити, яким чином факти реальної біографії трансформуються

14 П. Зайцев, Життя Тараса..., с. 349.

15 I. Кошова, „Поет і проза”. Тарас Шевченко - Ликера Полусмакова: спроба прочитання психологічного підтексту, [в:] Тарас Шевченко і народна культура: Збірник прачь Міжнародної (35-ої) наукової шевченківської конферениії [20-22 квітня 2004 року] у двох книгах, ред. В. Смілянська, кн. 2, Черкаси 2004, с. 314. 
у психобіографічні мотиви. Раціоналістична свідомість зазвичай ігнорує ті або ті істотні вказівки символічного характеру, поверхово класифікуючи їх як випадкові співпадіння або звичайний збіг обставин тощо, за чим в істоті нічого не криється. Натомість мистецтво ритуально-міфологічної інтерпретації дає адекватний ключ розуміння сугестивного психо-екзистенційого підтексту подібних промовистих вказівок. Своєю чергою, юнгіанська аналітична психологія вбачає в них прояв феномену синхроністичності, що грунтується на „«принципі акаузальних зв’язків» — таємничій єдності людської психе і матеріального світу, зумовленої тим, що в істоті вони є лише різними формами енергіï" 16 .

Різноманітні ритуально-культові рефлекси перебігу материнського комплексу уявнюють містичну присутність у людській і творчій свідомості Шевченка - цього вічного невтішного сироти - архетипально-нумінотичної мана-особистості Великої Матері ${ }^{17}$, котра узагальнює численні неусвідомлені мотиви як індивідуально-психобіографічного, так і колективного характеру. Саме вона домінує над бурхливими хвилями того аніматичного моря жінок, що періодично зринали на поверхню з глибин несвідомих сфер поетової душі.

Уже сама наявність тих чи інших іпостасей Великої Матері у ряді поезій інтимно-любовної тематики видається вельми показовим свідченням, тоді як відповідні мотиви набувають узагальненої сакрально-символічної якості золотого тла ікони. Так, у центральному фрагменті поезії Г. 3. (Немає гірше, як в неволі..., 1848), де поет-невільник натхненно оспівує гарно-молоду, прехорошу красу адресатки, — своєї співаної волі, єдиної, слухняної рожевої зорі тощо, - згадується власне „Мати! / Старесенька мати!”"18. За цим материнським образом стоїть Тетяна Волховська, власниця села Мойсівка (Мосівка) Пирятинського повіту Полтавської губернії, на бенкеті в якої 29 або 30 червня 1843 р. Шевченко познайомився з майбутньою адресаткою свого вірша Ганною Закревською.

Фактично у розглядуваному творі поряд поставлено „двох матерів”, що разом узяті еманують енергію особливої міфо-архетипальної „повноти”19. Щаслива й життєво сповнена „Старесенька мати!” органічно доповнює повнокровну центральну постать „молодої матері” на глибиннопсихологічній засаді „соincidentia oppositorum”20/ „єдності протиріч” (лат.).

Мотиви матері на різні лади звучать практично в усіх творах, де так чи інакше зринають спомини про Оксану Коваленківну. Передусім у поемі Мар'яна-черниця поряд з протагоністкою стоїть їі нібито й любляча, але ра-

\footnotetext{
16 D. Sharp, Leksykon..., c. 158. Тут і далі переклад з польської мій. - I. Б.

17 Ibidem, c. 116, 121-122, 154.

18 Т. Шевченко, Повне зібрання творів..., т. 2, с. 98-99.

19 D. Sharp, Leksykon ..., c. 123.

20 Ibidem, c. 46.
} 
зом 3 тим сувора й невблаганна мати-вдова, яка проти волі дочки хоче видати iii заміж не за коханого убогого Петруся, а за старого багатого сотника Івана.

Промовистий образ суворо-строгої родительки, емоційно стриманої та риторично небагатослівної, яка навіть не просила у Бога щастя для сина, виведено у вірші Не молилася за мене...: „Не молилася за мене, / Поклони не клала / Моя мати; а так собі / Мене повивала, / Співаючи. — Нехай росте / Та здорове буде!"21. Цей лаконічний материнський спів над немовлям передує молитовно-розпачливому благанню поета про тихе сімейне щастя у парі з судженою: „А я так мало, небагато / Благав у Бога, тілько хату, / [...] / Та безталанную мою, / Мою Оксаночку"22. Натомість у вірші Ми вкупочці колись росли... трагічну постать незабутньої першої коханої виведено на зловісно-понурому міфо-символічному тлі двох матерів - небіжчиць, яких з огляду на їх актуальну типологічну приналежність до потойбічного світу предків названо старими:

Ми вкупочці колись росли, / Маленькими собі любились, / А матері на нас дивились / Та говорили, що колись / Одружимо їх. Не вгадали. / Старі зараннє повмирали, / А ми малими розійшлись / Та вже й не сходились ніколи ${ }^{23}$.

У цілісному контексті психобіографії поета необхідно засигналізувати своєрідний „ономастичний” парадокс „двох Оксан”. Коріння проблеми криється в тому, що, подібно до міфів, деякі психобіографічні мотиви „без імен практично не існують”, оскільки обом типам свідомості - ритуально-міфологічної та індивідуально-творчої - „властиве розуміння імені як певної внутрішньої (глибинної) істоти” душі „його носія”24.

Ім'я Оксани по іронії долі носила не тільки перша ідеалізована кохана Шевченка - досконала репрезантантка сокровенно-аніматичних мотивів його індивідуально-творчого несвідомого, котра майбутнього митця „без мови, без слова навчила / Очима, душею, серцем розмовлять", — ділила 3 ним радість і тугу: „усміхалась, плакала, журилась”25. Тією другою стала інфернально-одіозна мачуха — „ще молода Оксана Терещенчиха, що овдовіла [...] iз трьома малими дітьми" 26 . Маючи виразно незрівноважену/дезінтегровану психіку, своєю тіньовою поведінкою 27 вона обернула життя „родини Шевченків [...] у справжнє пекло”, причому „найгірше в тому родинному пеклі було Тарасові”, який вочевидь боявся „попасти на очі лютій мачусі”28. ІЇ̈ ненависть переслідувала пасинка навіть тоді, коли вони вже не жили під одним дахом.

21 Т. Шевченко, Повне зібрання творів..., т. 2, с. 212.

22 Ibidem.

23 Ibidem, c. 203.

24 Див. В. Н. Топоров, Имена, [в:] Мифы народов мира: Энциклопедия: Электронное издание, предисл. С. А. Токарев, Е. М. Мелетинский, ред. С. А. Токарев, Москва 2008, с. 418-420.

25 Т. Шевченко, Повне зібрання творів..., т. 1, с. 192.

26 П. Зайцев, Життя Тараса ..., с. 16.

27 D. Sharp, Leksykon ..., c. 43-46.

28 П. Зайцев, Життя Тараса..., с. 17, 23.

Slavica Wratislaviensia 173, 2020

(C) for this edition by CNS 
На думку Карла Густава Юнга, „життя родиться виключно $з$ іскри, викресаної суперечностями”, й „чим більша напруга між їхніми парами, тим більша буде енергія, що іiї вони витворять" ${ }^{\prime 2}$. Цей глибоко символічний феномен complexio oppositorum (буквально: суперечностей, виражених в єдиному образі (лат.), а в даному разі - в одному імені двох взаємовиключних Оксан, de facto, двох полярних архетипально-аніматичних іпостасей - ангельської та демонічної - як індивідуальної психе, так і колективного несвідомого ${ }^{30}$ ), ймовірно, був витіснений зі свідомості митця. Але тим істотніший, хоча й опосередкований вплив мав він справити на творчу уяву поета, активізуючи у несвідомих сферах його травмованої психіки компенсаторно-терапевтичну діяльність трансиендентальної функиії ${ }^{31}$, м. ін., шляхом посиленого генерування високосугестивних художніх мотивів міфо-архетипального характеру.

Зовнішнім рефлексом усіх цих складних глибиннопсихологічних процесів могла бути, зокрема, ота властива Шевченкові часта зміна полярних емоційних станів і настроїв. На рівні поетики вона знайшла адекватний вираз у бінарно-опозитивних мотивах раю і пекла (запаленого раю, пекельного вогню), а ії чи не найдосконаліше мистецьке відтворення становить знаменитий вірш 1847 p. N. N. (Мені тринадиятий минало...). Цей текст з його загадковим криптонімом, що не піддається однозначній атрибутації, (а також із однозначно не окресленим станом свідомості: неясно, чи описувані події відбувалися на яві, чи уві сні, чи у видіннях активної імагінації), у контексті закономірностей поетової психобіографії міг бути інспірований виключно постаттю коханої Оксани. Що більше, „дівчина”, яка вивела підлітка з розпачливо-депресивного душевного стану: „Прийшла, привітала, / Утирала [...] сльози / I поцілувала..."32, — постає ніби на непроговорено-неусвідомленому архетипально-тіньовому тлі злої мачухи (теж Оксани — i теж не названої по імені), адже це саме вона запалила благословенний Богом родинний рай, позбавивши сироту не тільки його рідної хати, але передусім радості буття тощо.

Засадничі мотиви поезій Ми вкупочці колись росли... та N. N. (Мені тринадиятий минало...), а почасти також і поеми Мар'яна-черниия виразно відлунюють у віршах 1860 р., інспірованих стосунками з Ликерою, в образі якої проступають архетипально-амбівалентні риси обох Оксан. Комплексне прочитання цих творів як своєрідного психо-екзистенційного циклу прояснює деякі сокровенні аспекти Шевченкової творчості та психобіографії.

Вірш Росли укупочиі, зросли... було написано 25 червня 1860 р., за місяць перед сватанням до Ликери ${ }^{33}$. У цьому творі поет відчайдушно намагається

29 D. Sharp, Leksykon..., c. 136-137.

30 Ibidem, c. 46, 112-113, 141.

31 Ibidem, c. 63-65.

32 Т. Шевченко, Повне зібрання творів..., т. 2, с. 36-37.

33 Ликерою Шевченко познайомився ще у перші місяці 1860 p., ,але увагу на неї звернув він” не раніше травня або й у червні — „вже тоді, коли справа зі сватанням до Харити” Довгополенківни (1841-?) „виявилася безнадійною” (Зайцев, с. 348). Див. також: А. Ткаченко, 
по-новому — цього разу на щасливо - переписати той негативно-профанний сценарій лихої долі, що був зафіксований у поезії Ми вкупочцุі колись росли... й тотально суперечив як життєвим планам самих закоханих, так і добрій волі обох їх матерів, котрі у відповідний час мріяли одружити своїх дітей. Отже, втрачену колись гармонію, як особисту, так і світову, — отой талан, що Гоcnoдb його, „може, й дав, та хтось украв, / I одурив святого Бога”34, — тепер треба неодмінно віднайти:

Росли укупочці, зросли; / Сміятись, гратись перестали. / Неначе й справді розійшлись!.. / Зійшлись незабаром. Побрались; / І тихо, весело прийшли, / Душею-серцем неповинні, / Аж до самої домовини. / А меж людьми ж вони жили! ${ }^{35}$

У процитованих рядках також недвозначно відлунює мотив ще одної великої несповненої любові, який свого часу трагічно прозвучав у поемі Мар’яна-черниця: „Отак вони любилися! / На той світ хотіли / Обнявшися переступить; / Та не по-їх стало!"36. Тим часом у розглядуваному вірші не названих по іменам закоханих спіткало правдиве людське щастя, яке раніше не судилося ні Мар'яні з Петрусем, ані Оксані з Тарасом. Відтак у другій строфі вірша з усією силою свого поетичного генія митець благає всещедрого Бога зробити можливим його особисте щастя. Цей мотив уже звучав у поезії Не молилася за мене..., але якщо тоді мріялося про ідилічне життя: про „хатиночку в гаю” та прогулянки 3 коханою „Понад Дніпром у темнім гаї”37 тощо, - то тепер екзистенційні пріоритети повністю перейшли у психо-духовну сферу: „одружитися і йти, / Не сварячись в тяжкій дорозі, / [...] / Любов безвічную, сугубу / На той світ тихий принести"з3.

На самому початку цього оновленого, як здається поетові, етапу його життя далі лишається актуальним мотив ритуально-міфологічної ідеалізації обранки. У листі до Макарова від 30 липня 1860 р. Шевченко із захопленням висловився про неї: „розумна і щира душа”39. Але тепер, на відміну від колишнього сироти, щзо „в сірій свитині, бувало, щасливий, / Як побачить диво — [...] красоту" Оксани ${ }^{40}$, — у вірші Ликері увагу поета сконцентровано не на привабливій зовнішності, а на вимріяних рисах особистості адресатки та його відчайдушних планах гармонійного поєднання доль двох cupim-невільників: „Моя ти любо! усміхнись / I вольную святую душу / I руку вольную, мій друже, / Подай мені"41.

Полусмак Ликера, [в:] Шевченківська енииклопедія у шести томах, т. 5, ред. В. Смілянська, Київ 2015, с. 249.

34 Т. Шевченко, Повне зібрання творів..., т. 2, с. 204.

35 Ibidem, c. 349.

36 Т. Шевченко, Повне зібрання творів..., т. 1, с. 195.

37 Т. Шевченко, Повне зібрання творів..., т. 2, с. 212.

38 Ibidem, c. 349.

39 П. Зайцев, Життя Тараса..., с. 355.

40 Т. Шевченко, Повне зібрання творів..., т. 1, с. 192.

41 Т. Шевченко, Повне зібрання творів..., т. 2, с. 351.

Slavica Wratislaviensia 173, 2020

(C) for this edition by CNS 
В останніх рядках вірша Ликері знову відлунює лейтмотив хати, що $€$ одним із ключових у Шевченковій інтимно-любовній ліриці. Але й він озвучується у контексті нової психобіографічної парадигми: „В хатині тихій і веселій” поет у щасливому подружжі сподівається остаточно „поховать лихе дебеле" ${ }^{\prime 2}$. Тим часом його нібито ідилічний відгомін у перших рядках вірша Л.: „Поставлю хату і кімнату, / Садок-райочок насаджу” 43 , — насправді відкриває останню трагічну сторінку особистої психодрами поета, що роковим чином наблизила фінал його сповненого страждань життя.

Коли пов'язувані з новою обранкою ілюзії швидко розвіялися, з глибин творчої свідомості митця знову зринув моторошний образ-символ запаленого раю. Фігуруючи у вірші Л. (Поставлю хату і кімнату...), свою безпосередню генезу він виводить з поезії $N$. N. (Мені тринадиятий минало...), а опосередковану — також із тексту III. (Мені однаково, чи буду...) з циклу В казематі (1847). Показово, що понура сугестія цього архетипального образу-символу в усіх трьох контекстах посилюється мотивами кошмарного сонного марення - i ще жахливішого пробудження у реальне життя. У ретроспективі цей типологічний ряд вимальовується наступним чином - пор.:

Давнє-колишній та ясний / Присниться сон мені!.. I ти!.. / Ні, я не буду спочивати, / Бо й ти приснишся. I [в] малий / Райочок мій спідтиха-тиха / Підкрадешся, наробиш лиха... / Запалиш рай мій самотний 44 ;

Та недовго сонце гріло, / Недовго молилось... / Запекло, почервоніло / I рай запалило. / Мов прокинувся, дивлюся: / Село почорніло, / Боже небо голубеє / I те помарніло ${ }^{45}$;

Та неоднаково мені, / Як Україну злії люде / Присплять, лукаві, і в огні / ІЇ̈, окраденую, збудять... / Ох, не однаково мені ${ }^{46}$.

Аналіз психобіографічного підгрунтя Шевченкової інтимно-любовної лірики переконує в тому, що в особі Ликери увагу поета привертали передусім соціально-родові типологічні риси кріпачки-сироти, які в особливий спосіб ріднили іï з Оксаною Коваленківною, та й і з самим поетом. Тим більше індивідуально-особисті „моральні вади [...] нареченої”, які митець „поясняв «рабством» (мовляв, «воля і достаток» змінять ії на краще)”, спонукали його взяти „на себе місію врятувати від падіння цю темпераментну дівчину” ${ }^{47}$. Відтак „думка не допустити повторення” в реальному житті літературно-художнього парадигматичного сценарію

долі Оксаночки, тільки, можливо, в якому-небудь «столичному» варіанті, оволоділа уявою поета. Він, здавалося йому, знайшов простоту, поєднану з чарівною зовнішністю, так щільно зв'язані з образом Оксани ${ }^{48}$.

42 Ibidem, c. 351.

43 Ibidem, c. 354.

44 Ibidem, c. 354.

45 Ibidem, c. 36.

46 Ibidem, c. 13.

47 Ibidem, c. 352.

48 П. Зайцев, Перше кохання Шевченка, [в:] П. Зайцев, Перше кохання Шевченка; В. Петров, Романи Куліша, Аліна й Костомаров, Київ 1994, с. 14. Реальна Оксана Коваленко покрит-

Slavica Wratislaviensia 173, 2020

(C) for this edition by CNS 
Поет мріяв офірувати нареченій „свою довічну любов і батьківську опіку"49, а їі неспроможність доцінити це знов захитала у його душі підвалини світопорядку, який, здавалося, вже починав відновлюватись. Звідси, зокрема, у вірші Л. (Поставлю хату $і$ кімнату...) на полотні творчої уяви митця: „Присняться діточки мені, / Веселая присниться мати" 50 , - сакральний материнський образ-символ витісняється профанною постаттю адресатки - тіньової особи, що недвозначно асоціюється 3 лютою мачухою, котра свого часу запалила родинний рай поета, а тепер - заповітну мрію про нього. А що у художньому світі Шевченка архетипальна Велика Мати виступає одною з найпоказовіших іпостасей рідної землі, то ця тіньова фігура виразно поляризується 3 нею, відповідно тяжіючи до силового поля злих, лукавих людей, які його „Україну [...] окраденую” приспали, підпалили й збудили „в огні”,51.

Аналіз психобіографічного підгрунтя інтимно-любовної лірики Шевченка остаточно наводить на думку, що фактично у святая святих його психе панували лише дві жінки: мати, котра вельми рано осиротила майбутнього митця, — й усі інші. При цьому абсолютну буттєво-духовну вартість кожної 3 цих інших для себе поет визначав залежно від того, до якої $з$ двох архетипальних материнських іпостасей — сакральної чи профанної - вона тяжіє.

\section{Бібліографія}

Barabaš Û., Lûbov (kohannâ, zahoplennâ, pristrast', upodobannâ, pasiâ), [v:] Temi ì motivi poezï Tarasa Ševčenka, uporâd., red. N. Čamata, Naukova dumka, Kiïv 2008.

Franko I., Zìv 'âle listâ. Lirična drama, ìdeâ ta koncepciâ vidannâ, pìslâmova M. Zubric'ka, uporâd., pìdgotovka tekstìv, nauk. ta lìt. red., pošuk tafotokopîuvannâ arhìvnih džerel B. Tiholoz, Litopis, L'vìv 2006.

Jejts F., Iskusstvo pamâti, per. E. Malyškin, Universitetskaâ kniga, Sankt-Peterburg 1996.

Košova I., ,, Poet i proza”. Taras Ševčenko - Likera Polusmakova: sproba pročitannâ psihologičnogo pidtekstu, [v:] Taras Ševčenko ì narodna kul'tura: Zbirnik prac' Mižnarodnoï (35-oï) naukovoï ševčenkivs'koï konferenciï [20-22 kvitnâ 2004 roku] u dvoh knigah, red. V. Smilâns'ka, kn. 2, Brama - Ukraïna, Čerkasi 2004.

Modi memorandi: Leksykon kultury pamięci, red. M. Saryusz-Wolska, R. Tadla, spìvpr. J. Kalicka, Wydawnictwo Naukowe Scholar, Warszawa 2014.

Tkačenko A., Polusmak Likera, [v:] Ševčenkìv'ka enciklopediâ u šesti tomah, t. 5, red. V. Smìlâns'ka, Nacìonal'na Akademiâ nauk Ukraïni, Kiïv 2015.

Toporov V. N., Imena, [v:] Mify narodov mira: Ènciklopediâ: Èlektronnoe izdanie, predisl. S. A. Tokarev, E. M. Meletinskij, red. S. A. Tokarev, Sovetskaâ Ėnciklopediâ, Moskva 2008.

Sharp D., Leksykon pojęć i idei C. G. Junga, przeł. J. Prokopiuk, Wydawnictwo Wrocławskie, Wrocław 1998.

кою не була. 30 січня 1840 р. вона вийшла заміж за кріпака з села Пединівка й мала у шлюбі двох дочок.

49 П. Зайцев, Життя Тараса..., с. 353.

50 т. Шевченко, Повне зібрання творів..., т. 2, с. 354.

51 Ibidem, c. 13.

Slavica Wratislaviensia 173, 2020

(C) for this edition by CNS 
Ševčenko T., Povne zibrannâ tvorìv u šesti tomah, t. 1: Poeziâ 1837-1847, uporâd. ta kom. Ì. Bažinov ta ìn., perednê slovo İ. Dzûba, M. Žulins'kij, red. V. Borodìn, Naukova dumka, Kiïv 2003; t. 2: Poeziâ 1847-1861, uporâd. ta kom. V. Borodin ta in., red. V. Borodìn, Naukova dumka, Kiïv 2003.

„,Toj lûbit' Fannì Bron, toj lûbit' Beatriče..." Lìna Kostenko, Osvita.ua, http://osvita.ua/school/literature/k/70272/.

Zajcev P., Perše kohannâ Ševčenka, [v:] P. Zajcev, Perše kohannâ Ševčenka; V. Petrov, Romani Kuliša, Alina j Kostomarov, Ukraïna, Kiïv 1994.

Zajcev P., Žittâ Tarasa Ševčenka, Naukove tovaristvo ìm. Ševčenka, N'û-Jork-Pariž-Mûnhen 1955.

\section{Psychological and Symbolic Biography as the Basis of Taras Shevchenko's Intimate Love Poetry}

\section{Summary}

This article attempts to analyze Taras Shevchenko's intimate love poetry in the context of his psychological and symbolic biography. In his love poems, the archetypal figure of the Great Mother, which maintains the balance of spiritual values in the area of s acred/profane dominates the images of beloved women. That is why ideal lyrical heroines are consistently contrasted with demonic ones.

Keywords: Taras Shevchenko, intimate lyrics, psychological and symbolic biography

\section{Psychologiczno-biograficzne podłoże intymnej liryki miłosnej Tarasa Szewczenki}

\section{Streszczenie}

W artykule podjęto próbę interpretacji intymnej liryki miłosnej Tarasa Szewczenki w kontekście psychologiczno-symbolicznej biografii poety. Okazuje się, że kreowanie obrazów ukochanych kobiet w poezji Szewczenki jest uwarunkowane archetypiczną postacią Wielkiej Matki, która utrzymuje równowagę wartości duchowych w zakresie sacrum/profanum. Powoduje to konsekwentne przeciwstawianie się bohaterek lirycznych: tych idealnych — tym demonicznym.

Stowa kluczowe: Taras Szewczenko, liryka intymna, biografia psychologiczno-symboliczna 